\title{
TJARITA KI-ASDOERA. HET VERHAAL VAN KI-ASDOFRA.
}

TEKS'T, VERTALING EN AANTEEKENINGEN, MET EENE INLEIDING EN OPMERKING OVER DE SPREEKTAAL IN ZUID-BANTĕN.

DOOR

J. J. MEIJER,

Voormalig kontroleur van Goenoeng Kantjana (Zuider Regentschap van Bantěn).

\section{IN LEIDIN G.}

"Het verschil tusschen het Zuid-Bantěnsch en het Preangersch is niet zoo groot als men wellicht zou denken", zoo beweerde ik in mijne studie over eerstgenoemd dialect der Soendaneesche taal, opgenomen in de April-aflevering van 1890 van dit tijdschrift.

De volgende bladzijden mogen als een bewijs voor die stelling gelden.

Het daar meêgedeelde verhaal is woordelijk uit den mond van den verteller opgeschreven. Het werd gedaan aan den wadana van Paroeng Koedjang. De spreker was een gewone landbouwer, die tevens het beroep van p a n ing g a ra n uitoefende. Als tijgerjager had hij een grooten naam. Ieder in de zuidelijke districten van het Zuider- en Wester-Regentschap kent Ki-Asdoera uit de desa Panjatjaran. Door de bevolking geëerd, bij de inlandsche ambtenaren geacht, had hij daardoor eene zekere vrijmoedigheid over zich, die men niet licht bij een gewonen desaman zou vinden.

Zijne veelvuldige aanrakingen met de parajai's of de menak menak, die hem steeds met onderscheiding behandelden, - o.a. mocht hij in hunne tegenwoordigheid rooken, - hebben zijne taal beschaafd, dat wil zeggen, dat hij van hen een zeker aantal lĕm ĕswoorden heeft overgenomen en ze te hooi en te gras bezigde.

Zooals hij met den wadana van Paroeng Koedjang sprak, sprak hij met de regenten van het Zuider- en Wester-Regentschap, 5e Volgr. VI. 
met den toenmaligen Assistent-Resident van $\mathrm{Tjaring}$ in ${ }^{\mathbf{1}}$, den heer A. E. van der Meulen, die de volkstaal kent als een geboren Soendanees, en met mij.

Het begin van het onderhoud kenmerkte zich door betrekkelijk veel lĕmĕswoorden. Gaandeweg werden zij schaarscher en wanneer het gesprek ten einde liep, bepaalden zij zich tot de voornaamwoorden. Het sierlijke gamparan makte dan zelfs plaats voor het meer alledaagsche a djĕngan. Zoo hooren wij hem nampi, doengkap, boemi, ladjĕng gebruiken, terwijl wij aan het slot van zijn verhaal slechts aan het woord koering merken, dat zijn toehoorder zijn meerdere en niet zijn mindere was. Toch zou hij niet vergeten om naar landsgebruik af en toe een sĕm $\mathrm{bah}$ te maken.

Evenals Ki-Asdoera spreken de meestedjaro's; alleen leveren de voornaamwoorden van den eersten persoon verschil op. Zelden bedienen zij zich van koering, wanneer zij reeds eenigen tijd in functie zijn. Al spoedig worden zij gewaar, hoe aangenamer djisim k oering, abdi, djisimabdi in de ooren der superieuren klinken. Pas verkozen desahoofden begaan te dien opzichte wel eens vergissingen.

Wil men weten, hoe desalieden onder elkander spreken, men vervange eenvoudig alle lĕm ĕswoorden door woorden uit de basa kasar, uitgezonderd die, welke vitsluitend op hooggeplaatste personen betrekking hebben, zooals piwarangan, soemping, pangsarean, doewoehan.

De inlandsche ambtenaren stellen zich niet tevreden met de lĕměswoorden van Preangerschen oorsprong. Onderscheidene krama

1 Deze naam wordt gewoonlijk - o.a. ook in het standaardwerk van Prof. P. J. Veth: Java, Geographisch, Ethnologisch, Historisch, Dl. III. Derde Hoofdstuk, - verbasterd tot $\mathrm{T}$ ji ringin en beschouwd als samengesteld uit de woorden $t j i$ en ringin, op dezelfde wijze als zijn ontstaan de namen Tji-Manoek, Tji-Taroem, Tji-Pamali. Te vergeefs heb ik in die streken gezocht naar de beteekenis van het woord ringin; niemand kende het. In Coolsma's Soendaneesch Nederlandsch woordenboek komt het ook niet voor. De bevolking spreekt dien naam altijd uit als Tjaringin, on ik geloof, dat de eenige verklaring deze is, dat de door de vloedgolf verwoeste hoofdplaats dezer afdeeling geneemd is naar den ons bekenden boom, die in het Soendaneesch tjaringin,


Artocarpeae. Tal van plaatsen in dat gedeelte van Bantěn danken haren naam aan den een of anderen boom: Kopo, Kadoe, Djangkoeng, Kalapa Satangkal, Djatake. In den regeeringsalmanak voor 1891 vinden wij de spelling Tjaringin. 
woorden zijn door Noord-Bantěnsche hoofden in Zuid-Banten ingevoerd. Zoo is het lĕmes woord voor djaro: djantěn, voor sore: sontĕn, voor isoek: endjing, enz. ${ }^{1}$

Ik heb gemeend, dat het verhaal van $\mathrm{Ki}-\mathrm{Asdoera}$ een goed voorbeeld van de spreektaal in $\mathrm{Zuid-Bantěn} \mathrm{oplevert.}$

Zonder onnoodige borduursels vertelt hij daarin zijne wederwaardigheden zoo natuurlijk mogelijk. Hem werd geen verhoor afgenomen; men beschouwe het daarom niet als het schriftelijk relaas van een gerechtelijk onderzoek.

Verdient het om die reden reeds anbeveling, mij herinnert het bovendien aan eene der aangenaamste episoden uit mijn diensttijd in de residentie $B$ ant ĕn.

De aanteekeningen behelzen eenige bijzonderheden en opmerkingen van ethnographischen aard aangaande het Zuider- en WesterRegentschap.

Misschien kunnen jongere ambtgenooten, die later in die streken geplaatst mochten worden, of andere personen, die er zich gaan vestigen, daarmede hun voordeel doen. Voor velen is dat deel van het gewest nog eene terra incognita.

Bussum, Augustus 1890.

1 Volgens den heer Coolsma hoort men ook in de Preanger-Regentschappen sontěn en endjing als lěměswoorden van sore en isoek. 


\section{TJARITA KI-ASDOERA (1)}

Mimitina koering nampi piwarangan djoeragan astiten wadana Moendjoel, jen koering koedoe leumpang ka Panimbang; harita mĕnĕran poë salasa, teu ingět boelanna djeung tanggalna. Barang isoekna poë rěbo bral koering leumpang ka Panimbang sĕrta mawa djēlěma rejana gĕnĕp poeloeh djeung djaro ngaran Asdoera, nja eta anak koering.

Barang koering doengkap (2) ka Panimbang geus njampak djoeragan patih Tjaringin di boemina djoeragan wadana. Tidinja koering ladjĕng ngadeuheus $\mathrm{ka}$ djoeragan wadana djeung ka djoeragan patih; děmi timbalanana djoeragan patih: "Ajeuna maneh Bapa Asdoera hade njijar pamondokan (3) bae."

$\mathrm{Nja}$ koering meuting di masigit; doepi isoekna poë kĕmis koering diadjak leumpang ka Tjitěngah ngiring djoeragan patih djeung djoeragan wadana. Ari djělěma noe gěněp poeloeh teja hĕnteu dibawa, ditinggalkeun di Panimbang pikeun ngadjaga di kawadanan (4).

Noe ngiring djoeragan patih mah ngan baris (5) oepas oepas bae.

\section{HET VERHAAL VAN KT- ASDOERA}

Het begin was, dat ik van den assistentwadana van Moendjoel den last ontving om mij naar Panimbang te begeven; het was juist op een dinsdag, de maand en den dag herinner ik mij niet. Den volgenden morgen - woensdag - begaf ik mij naar Panimbang en nam met mij mede zestig personen, benevens het desahoofd Asdoera, mijn zoon.

Toen ik te Panimbang aankwam, ontmoette ik daar den patih vanTj a ring in in de districtshoofdswoning. Ik maakte vervolgens mijne opwachting bij den wadana en bij den patih; de patih zeide tot mij: "Bapa Asdoera, gij moest nu maar een nachtverblijf zoeken."

Ik overnachtte in de moskee; den volgenden morgen - donderdag - werd ik uitgenoodigd naar Tjiternga h te gaan om den patih en den wadana te vergezellen. De zestig personen werden niet medegenomen; zij werden te Panimb ang achtergelaten om de districtshoofdswoning te bewaken.

Het waren slechts oppassers, die den patih vergezelden. 
Poë harita keneh ngan tĕpi ka lěmboer (6) Djadjawaj, pěrnahna sakalereun Tjitĕngah. Toeloej meuting sapeuting.

Didinja geus njampak astitenwadana Katoembiri djeung astitenwadana Tjiseureuheun sĕrta njarandak pirang pirang djęlĕma pada sadija pakarang, kajaning bĕdil, golok, toembak, bĕdog, balijoeng, patjoel djeung lijan lijanna pakarang. Isoekna poë djamahat antero (7) djĕlěma djĕlĕma laleumpang ka pamatang Hoeloe Gawan (8), sakalereun Tjitěngah keneh. Barang geus koempoel kabeh di pamatang Hoeloe Gawan toeloej djoeragan patih miwarang ka hidji hadji, ngaran hadji Baris, meuleum mĕnjan tina sabab dek njatjar di pamatang Hoeloe Gawan (9) pikeun njijeun goeboeg pasagi. Saĕnggeusna eta hadji ngoekoes toeloej sakabeh djëlëma djĕlëma ngalatjar, lĕgana kira kira toedjoeh poeloeh toembak pasagi.

Barang anggeus njatjar pigoeboegeun, djoeragan patih nimbalan ka djoeragan wadana, jen eta djĕlĕma djëlĕma koedoe dibagibagi, pikeun ngala hoë opat poeloeh lima djělěma, ngala awi salapan poeloeh lima, ngala hateup opat poeloeh lima, ngala tjaï lima, sasesana ngarala kajoe (10) geusan piadjireun.

Ari noe ngala tjaï dikapalaän koe hidji hadji, ngaran hadji Tarminah, (11) djeung pangoeloe (12) Bodjong Koneng ; eta doewa djělěma beunang milih.
Dien dag kwamen wij slechts tot aan het gehucht $\mathrm{Dj}$ adjawaj, gelegen ten noorden van $\mathrm{Tj}$ it ĕngah. Wij bleven een nacht over. Daar ontmoetten wij de assistent wadana's van Katoembiri en Tjiseureuheun, die bij zich hadden tal van lieden voorzien van wapens, zooals geweren, kapmessen, pieken, hakmessen, bijlen, patjoels en andere.

Den volgenden dag - vrijdag - begaven allen zich naar den heuvelrug Hoeloe Gawan ten noorden van Tjitěngah.

Toen zij reeds verzameld waren op den heuvelrug Ho eloe Gawan, gaf de patih last aan een hadji, $\mathrm{h}$ a dji $\mathrm{B}$ a ri s genaamd, om wierook te branden, omdat men een stuk van het bosch op den heuvelrug Hoeloe Gawan wilde wegkappen om een vierkant wachthuiste bouwen. Nadat die hadji wierook gebrand had, begonnen allen het bosch weg te kappen, over eene uitgestrektheid van ongeveer 70 vierkante roeden. Nadat men het terrein voor het wachthuis had opengekapt, gaf de patih aan den wadana last om die lieden te verdeelen: vijf en veertig moesten rotting, vijf en negentig bamboe, vijf en veertig atěp, vijf water halen; de rest moest hout voor de staketsels halen.

$\mathrm{Z}_{\mathrm{ij}}$, die water haalden, werden aangevoerd door een hadji, genaamd hadji Tarminah, en door den pangoeloe van Bodjong Koneng. Deze twee lieden waren uitgezocht. 
Tapi eta noe ngala tjaï wĕleh teu meunang tjaï koe sabab disingsijeunan maoeng di djalan waktoe dek ngala tjaï di antara Tjitĕngah djeung goeboeg (13) Gawan. Toeloej baralik deui bae sĕrta oendjoekan ka djoeragan patih djeung $\mathrm{ka}$ djoeragan wadana jen maranehanana disingsijeunan maoeng.

Lahiran djoeragan patih: "Ajeuna "oelah ngala tjaï kadinja, kadijeu "bae ka kalereun goeboeg Gawan "mapaj djalan gĕde."

Toeloej ngarala tjaï kadinja bae.

Barang djęlěma noe ngarala hateup daratang, tjarita deui bae jen maranehanana dipĕgatan maoeng; malah meh teu meunang hateup.

Dĕmi hoë, awi, hateup djeung kajoe geus daratang, toeloej njijeun goeboeg.

Kira kira wantji ngarangsang eta djēlěma noe keur njarijeun goeboeg disĕntakan maoeng bari gĕgěroengan. Ger bae djĕlĕma sakitoe lobana laloempatan, teu ngoeroes djoeragan wadana atawa djoeragan patih (14). Ngan koering sorangan noe masih aja di dinja.

Tidinja djoeragan patih miwarang ngadjaga ka koering ti sabeulah timoerna (15) goeboeg; kakara djĕlĕma djëlĕma waraniëun deui digarawe.

Kira kira wantji tangange (16) koering dipiwarang ngoekoes deui koe djoeragan patih.

Ladjoe (17) koering ngoekoes
Maar zij, die water zouden halen, deden een vergeefschen tocht; zij kregen geen water, want zij waren onderweg, toen zij tusschen Tjitĕngah en het wachthuis $\mathrm{Ga-}$ wan water wilden halen, door een tijger bang gemaakt. De patih zeide: "Gaat niet daarheen water halen, gaat maar noordwaarts van het wachthuis $\mathrm{G}$ aw a n en volgt den grooten weg." Daarop gingen zij daarheen water halen.

Toen de lieden, die a tĕp haalden, terugkwamen, vertelden zij ook, dat zij door een tijger belet waren voort te gaan. Zelfs hadden zij bijna geen a tĕp gekregen.

Nadat de rotting, bamboe, a tĕp en het hout gekomen waren, ging men tot den bouw van het wachthuis over. Ongeveer tegen den middag werden de lieden, die het wachthuis bouwden, door een gebrul op de aanwezigheid van een tijger opmerkzaam gemaakt. Allen gingen op den loop en zagen in het geheel niet om naar den patih of den wadana. $\mathrm{lk}$ alleen was nog daar. Daarop gelastte de patih mij om ten oosten van het wachthuis de wacht te houden; toen eerst durfden de lieden weder-aan den arbeid gaan.

Ongeveer tegen twaalf uur gelastte de patih mij om weder wierook te branden.

Toen ging ik wierook branden 
barateun (18) djalan, ngahareup (19) ka barat (20).

Ti barang koering geus ngoekoes, bĕrkah (21) salamĕt, teu aja kitoe kijeu deui datang ka boerit, sěrta noe digarawe pada djongdjon datang ka anggeus eta goeboeg.

Sarengsena (22) goeboeg sakabeh djĕlěma djĕlěma ngiring parajaï(23) balik moro menting ka Djadjawaj deui. Ari koering leumpangna mapaj sisi djalan bae tina ngadjaga djoeragan patih djeung djoeragan wadana.

Barang datang ka sisi lĕmboer Djadjawaj djaro desa (24) Tjigabig ngaran Saneh leumpangna pangheulana; didinja gĕr deui dipĕgatan maoeng; tapi teu aja noe kitoe kijeu, djĕlěma djĕlěma madjoe bae moro pamondokan ka Djadjawaj.

Dikira poekoel satĕngah doewa bělas peuting malĕm saptoe koedana djoeragan patih djeung koeda djoeragan wadana di kolong ngamoek (25) teu kira kira; djĕlěma sakitoe lobana wĕleh teu aja noe wani toeroen.

Nja koering maksa maneh toeroen ngawaskeun eta koeda, koe naon sababna noe matak ngamoek, tapi teu kapanggih naon naon.

Barang isoekna poë saptoe isoek isoek diilikan oeroetna, aja tapak maoeng noöng koeda. Geus kitoe toeloej sakabeh djĕlěma djĕlĕma ngiring djoeragan patih pindah ka goeboeg Gawan bari marawa hateup pikeun ngahateupan goeboeg Tjitěngah. ten westen van den weg, met mijn aangezicht naar het westen gekeerd. Nadat ik wierook gebrand had, werd het rustig; er gebeurde niets tot den avond; zij, die arbeidden, konden ongestoord het wachthuis voltooien. $\mathrm{Na}$ de voltooiing van het wachthuis vergezelden de lieden de ambtenaren om weder te $\mathrm{Dj}$ adjawaj te overnachten. Ik liep steeds aan den kant van den grooten weg, omdat ik op den patih en den wadana paste. Bij het gehucht Djadjawaj gekomen liep de djaro van Tjigabig, Saneh genaamd, vooraan. Hij werd in het voortgaan belet door een tijger, maar er gebeurde niets; de lieden vervolgden hun weg naar $\mathrm{Dja}$ djawaj om een nachtverblijf te zoeken. Ongeveer om half twaalf van vrijdagnacht werden de paarden van den patih en den wadana onder het huis in hevige mate onrustig. Onder zooveel personen was er geen enkele, die naar beneden durfde gaan. Ik sprak mijzelven moed in om naar beneden te gaan ten einde die paarden goed op te nemen, wat de reden was, dat zij zoo onrustig waren; maar ik merkte niets op. Toen men zaterdag morgen naar de plek ging kijken, waren er sporen van een tijger, die op de paarden geloerd had. Vervolgens verhuisden allen met den patih naar het wachthuis Gaw an en namen at ěp mede om daarmede het wachthuis te Tjitĕngah te bedekken. Toen wij aan het 
Barang doengkap ka goeboeg Tjitěngah, gĕr njatjar deui sĕrta patĕpoengan djeung djoeragan wadana Tjibalijoeng.

Djoeragan patih ngabagikeun pagawean ka doewa wadana. Ari wadana Tjibalijoeng dibagian njijeun doewa bělas kamar pikeun pangsarean (26) toewan toewan; ari wadana Panimbang dibagian ngadamĕl tĕmpat poetri djeung toewan pangeran, dapoer, kakoes djeung istal. Sapoë saptoe eta dangdanan anggeus.

Teu lila deui ti saänggeusna pagawean, djĕboel soemping kandjĕng toewan rĕsiden Rĕmbang diiring koe djëlěma djĕlěma; sĕrta toeloej papariksa (27) ka djoeragan patih djeung ka djoeragan wadana, koemaha pětana hal ngala maoeng.

Doepi pioendjoekna djoeragan patih: "Didijeu, kandjĕng toewan, teu aja noe bisa ngala maoeng ngan Ki Asdoera."

Toeloej koering disaoer koe kandjĕng toewan rĕsiden Rĕmbang. Saoerna: "Koemaha akalna ngala maneng?"

Pioendjoek koering: "Oepami aja maoeng ngahakan kĕbo atawa koeda sok di wělĕngan (28). Tidinja kandjěng toewan rěsiden Rĕmbang ngatoer ngadaměl ranggon (29) doewabĕlas, antjak (30) doewa ratoes.

Barang geus anggeus eta ranggon djeung antjak, djĕboel soemping toewan poetri, toewan pangeran, (31) kandjĕng toewan re- wachthuis van Tjitĕngah aankwamen, gingen wij weder het bosch wegkappen en vereenigden ons met den wadana van $\mathrm{Tjiba-}$ lijoeng. De patih verdeelde de werkzaamheden onder de twee wadana's. De wadana van Tjibalijoeng wert belast met de inrichting van twaalf kamers voor slaapvertrekken van de heeren; de wadana van Panimbang kreeg als zijn deel den bouw van het logies voor de Prinses en den Prins, van de keuken, het privaat en de stallen. Dien zaterdag werd dat alles voltooid. Niet lang na den aftoop der werkzaamheden kwam de resident van Rĕmbang aan, vergezeld van tal van menschen. Deze deed onderzoek bij den patih en den wadana hoe men het aanlegde om tijgers te vangen. Het antwoord van den patih luidde: "Hier, hoog edelgestrenge heer, is er niemand, die tijgers vangen kan, behalve Ki Asdoera." Vervolgens werd ik door den resident van R ĕmbang ontboden. Hị zeide: "Op welke wijze vangt men tijgers?" Ik antwoordde: "Wanneer een tijger een buffel of paard heeft opgevreten, wordt hij wel eens met een w ělěng gevangen." Daarop liet de resident van Rĕmbang twaalf $r$ anggon's en twee honderd antjaks vervaardigen. Toen die ranggon's en antjak's klaar waren, kwamen aan: de Prinses, de Prins, de resident van $B$ antĕn, de regent en andere heeren, gevolgd 
siden Bantĕn, kandjĕng dalĕm (32) djeung lijanna toewan toewan diiring koe parajai, djarodjaro djeung pirang djĕlěma.

Barang reup sore malěm ahad ladjoe masangkeun ěmbe mapaj djalan, kalereun goeboeg opat, kidoeleun goeboeg lima.

Eta ěmbe meunang sapeuting ditjangtjangna (33).

Barang isoekna poë ahad eta ĕmbe salapan aja keneh kabeh.

Barang sorena deui malĕm sĕnen eta ĕmbe ditjangtjangkeun sabeulah kidoelna Tjitĕngah sakalereun Tjisoewakan sĕrta ditoenggoe koe toewan poetri, ngahidji djeung toewan rĕsiden Rĕmbang.

Sakalereunana toewan pangeran djeung toewan toewan noe sedjen.

Djeung aja deui doewa toewan noe noenggoe di kidoeleun Tjisoewakan di sasak Tjirambětoek.

Ari kandjĕng dalěm noenggoena sabeulah kaler goeboeg Gawan.

Harita eta ĕmbe beunang koe maoeng hidji noe pangkalerna.

Ari koering noenggoe di Tjisoewakan djeung djoeragan wadana Tjibalijoeng.

Teu lila bělědoeg sora bĕdil, kandjĕng toewan rĕsiden Rĕmbang ngadjak moelih ka Tjitĕngah.

Tidinja koempoel di Tjitěngah; ngan toewan noe aja di Tjirambětoek tinggal didinja.

Ari djĕlĕma djĕlĕma noe loba meutingna masing masing bae: aja door inlandsche ambtenaren en tal van menschen. Toen de avond gevallen was, werden langs den weg geiten als lokaas gereed gezet, ten noorden van het wachthuis vier en vijf bezuiden het wachthuis. Die geiten bleven den geheelen nacht vastgebonden. Den volgenden morgen - zondag - waren zij er alle nog.

Zondag middag werden er weder gereed gezet ten zuiden van $\mathrm{Tj}$ itĕngah en ten noorden van $\mathrm{Tj}$ isoewakan. De Prinses bleef met den resident van $\mathrm{R}$ ĕmbang daar bij waken.

Ten noorden (van Tjitĕngah) bevonden zich de Prins en de andere heeren. Bovendien waren er nog twee heeren, die ten zuiden van Tjisoewakan bij de brug $\mathrm{Tj}$ irambĕtoek de wacht hielden.

De regent was geposteerd ten noorden van het wachthuis $\mathrm{G}$ aw an. Dien nacht werd een der geiten, de meest noordelijk geplaatste, door een tijger weggevoerd. Ik was geposteerd te $\mathrm{Tj}$ i s oe wak a n met den wadana van Tjibalijoeng. Niet lang daarna knalde een geweerschot; de resident van Rĕmbang noodigde allen uit om naar $\mathrm{T} j i$ tĕngah terug te keeren. Daarop verzamelden allen zich te Tjitěngah; slechts de heeren, die te Tjiramb ĕtoek waren, bleven achter.

De menigte overnachtte naar verkiezing; er waren er, die in het 
noe dina goeboeg, aja noe di leuit, tina sabab teu tjoekoep ěnggon.

Barang kira kira tĕngah peuting malěm sěnen aja sora maoeng djeung sora djĕlĕma gagawokan.

Ari gĕr diboro koe djĕlĕma loba, njata jen aja djĕlěma koe maoeng (34) ti leuit ngaran Saiman. (35)

Peuting harita keneh ladjoe disoesoel, dikira meunang gĕnĕp atawa dalapan toembak djaoehna teu kapanggih.

Tina sabab geus teu kapanggih bae, kandjĕng toewan rĕsiden Rĕmbang mariksa ka koering: "Koemaha ijeu djëlëma geus djaoeh kira kira dibawana?"

Pioendjoek koering kantěnan geus djaoeh.

Ladjĕng kandjĕng toewan rĕsiden Rĕmbang ngĕrsa moelih bae.

Tidinja bral sakabeh ka pamondokan. Harita di dinja tĕritoeng (36) roesoeh. (37)

Geus kitoe aja timbalan kandjĕng toewan rěsiden Rĕmbang, jen eta doewa toewan noe aja di Tjirambětoek koedoe ditejang.

Tidinja kandjĕng dalěm miwarang ka djoeragan patih djeung ka djoeragan wadana sěrta ka baris astiten, nja eta astiten Katoembiri, astiten Moendjoel djeung astiten Tjiseureuheun, sěrta mantri oeloe oeloe; tapi teu pati aja noe wani.

$\mathrm{Nja}$ eta baris astiten njaoer koering soepaja nejang eta doewa toewan ka Tjirambětoek. wachthuis overnachtten; er logeerden ook lieden in de schuren, omdat er geen plaats genoeg was. 's Nachts ongeveer ten half twaalf ure hoorde men het geluid van een tijger en tegelijkertijd een mensch schreeuwen.

Toen men zich daarheen begaf, kreeg men zekerheid, dat een man, S a i m a n genaamd, door een tijger uit eene schuur was weggehaald.

Men ging hem achterna dien nacht nog tot op een afstand van zes of acht roeden, maar vond hem niet. Daar men hem niet gevonden had, vroeg de resident van $R$ ĕmbang mij: "Hoe is het, zou die man al ver weggevoerd zijn?"

Ik antwoordde, dat hij zeker al ver weggevoerd moest zijn.

Daarop wilde de resident van Rĕmbang terugkeeren.

Allen begaven zich naar hun nachtverblijf. Verder bleef het onrustig.

De resident van $R$ ĕmbang gaf last, dat de heeren, die te $\mathrm{Tj}$ irambětoek waren, afgehaald moesten worden.

De regent trachtte het te laten doen door den patih, de wadana's en assistent wadana's, namelijk de assistent wadana van $\mathrm{K}$ atoembiri, Moendjoel, Tjiseureuheun, en den mantrioeloe o eloe, maar zij durfden geen van allen.

De assistent wadana's riepen mij, opdat ik die twee heeren te $\mathrm{Tj}$ irambětoek zou gaan halen. 
Toeloej koe koering ditejang djeung baris astiten serrta mawa djĕlěma noe mawa obor djeung pada sadija pakarang bědil, toembak djeung golok.

Ladjoe eta toewan balik ka Tjitěngah kaboeroe beurang poë sěnen.

Sadatangna koering ti Tjirambětoek sakabeh djĕlěma djělěma djeung toewan toewan geus njaroesoel noe koe maoeng ka leuweung.

Teu lila tamoe bangkena; ari noe geus dihakan biritna, pingpingna djeung raranganana.

Toeloej eta bangke diingkeun bae harita mah, sabab djĕlĕma djĕlěma masing masing pada njatjar geusan noenggoe maoeng, sěrta eta ranggon ditjarahtjalkeun ngaler ngidoel. Tidinja kakara (38) digiring make antjak, hidji antjak dibawa koe dalapan djĕlěma. Noe ngatoer ngatoer ngagiring kandjĕng toewan koentoelijoer Goenoeng Kantjana, djeung kandjĕng toewan koentoelijoer Mĕnes, djoeragan patih, djoeragan wadana Tjibalijoeng, Panimbang. djeung baris astiten astiten sĕrta pada sadija bĕdil, golok, toembak (39).

Tapi maoengna teu kapanggih.

Dĕmi eta bangke ditjangtjang kana toenggoel ditalian leungeunna.

Ari reup sore malěm salasa ditoenggoe koe doewa toewan.

Kira sareureuh eta maoeng datang
Daarop ging ik hen halen met de assistent wadana's en met lieden, die flambouwen droegen en voorzien waren van wapens, als geweren, lausen en kapmessen.

Maandag morgen met het aanbreken van den dag keerden die heeren naar Tjitěngah terug.

Bij mijne terugkomst van $\mathrm{Tji}$ $r a m b$ to oek hadden de lieden den man, die door een tijger was weggevoerd, reeds in het bosch nagevolgd.

Het lijk was reeds gevonden; verteerd waren de billen, de dijen en het schaamdeel.

Men liet het lijk dien dag aan zijn lot over, omdat de lieden het bosch moesten wegkappen om op den tijger te kunnen jagen. De rangg on s werden in eene noordelijke en zuidelijke richting opgesteld. Vervolgens werd met de antjaks opgedreven. Elke antjak werd gedragen door acht personen. Die het opdrijven regelden, waren de kontrôleurs van Goenoeng Kantjana en Mĕnes, de patih, de wadana's van Tjibalijoeng en Panimbang en de assistent wadana's, zij waren voorzien van geweren, kapmessen, pieken.

Maar de tijger werd niet gevonden.

Het lijk werd met zijne hand aan een boomstronk vastgebonden.

Maandagavond bleven twee heeren daarbij waken.

Omstreeks tegen acht uur kwam 
sĕrta dibědil tapi teu tĕnggĕl (40).

Toeloej kandjëng toewan rĕsiden njaoer ka koering ngadjak nejang kana eta bědil, gantjangna ditejang ka dinja. Barang geus tetela jen teu tĕnggĕl, toeloej moelih deui bae.

Kira kira wantji soeboeh koering ngiring kandjĕng toewan rĕsiden Rĕmbang nejang eta toewan noe noenggoe teja dina ranggon, ladjoe balik ka pondok.

Dina beurangna kandjĕng toewan rĕsiden Rĕmbang ngěrsakeun ningkěran (4l1) maoeng pikeun girimgeun, nja manggih oeroetna, malah kadenge sorana.

Ladjoe digiring deui sakoemaha tadi, tapi maoeng mah teu kapanggih deui bae. Tidinja gĕr ngagiring deui, tapi loepoet teu manggih deui bae.

Gantjangna ari reup peuting deui malěm rĕbo eta bangke ditoenggoe deui, malah ditambah ĕmbe dalapan, tapi eta peuting harita maoengna teu datang.

Ari isoekna toeloej dangdan sadija moelih; dikira poekoel dalapan isoek bral angkat moelih $\mathrm{ka} \mathrm{Pa}$ nimbang ladjĕng ka Mĕnes sĕrta diiring koe baris menak menak (42) djeung djaro șěkalian djělěma djělĕma.

Antara dalapan poë ti harita koering meunarg parentah ti nagara koedoe ngala maoeng di Tjitěngah djeung koering dipaparin doewit de tijger; er werd op hem geschoten, maar de kogel miste.

De resident (van $B$ antěn) riep mij en noodigde mij uit om naar het effect van dat schot te zien; $i k$ ging daarop daarheen. Toen ik mij verzekerd had, dat het een misschot geweest was, ging ik weder terug. Ongeveer ten vijf ure 's morgens vergezelde ik den resident van Rĕmbang, om de twee heeren, die in de ranggon (bij het lijk) waakten, te halen; daarop keerden allen naar het nachtverblijf terug. Toen het licht was geworden, verlangde de resident van Rĕmbang om het spoor van den tijger te volgen, ten einde eene drijfjacht te kunnen houden. $W_{i j}$ vonden het spoor en hoorden zelfs het geluid. Daarop hield men weder eene drijfjacht, maar de tijger werd niet gevonden. Noginaals werd er gedreven, doch te vergeefs, wij vonden niets. Dinsdagavond werd weder bij het lijk gewaakt; bovendien werden er acht geiten bijgevoegd; dien avond kwam de tijger evenwel niet.

Den volgenden morgen rustte men zich toe tot den terugtocht; ongeveer acht ure keerde men terug naar Panimbang en vervolgens naar M ĕnes, vergezeld van menak's, djaro's en lieden uit het volk.

Ongeveer acht dagen later ontving ik last uit de hoofdplaats om te Tjitĕngah tijgers te vangen en ik kreeg acht gulden om geiten 
dalapan roepijah geusan meuli ĕmbe djeung obat satjarak. $\mathrm{Nja}$ koering leumpang mawa djĕlěma salawe, ěmbe opat djeung běběkĕlan kajaning bejas, minjak, oejah, bako, seupaheun djeung lijanna.

Barang koering datang ka Tjitěngah ladjoe bae dangdanan wělěng, tapi ngan kaboeroe njijeun hidji di oeroet djĕlĕma noe koe maoeng teja.

Ari ĕmbe noe taloe (4i3) deui diteundeun di goeboeg Gawan; ari koering moro mondok mah ka lěmboer Djadjawaj.

Ari isoekna eta wělěng ditejang, barang geus tetela jen eta bĕdil beukas, koering geus atiati bae, bĕt teu kanjahoan deui eta maoeng sĕgoer (44) bae, mogok (45) bari njĕntakan.

Tidinja djĕdor dibědilan kira gěněp kali, teu lila eta maoeng paeh, ladjoe dirasah, koelitna djeung hoeloena dibawa ka Mĕnes poë harita keneh sĕrta disanggakeun ka kandjĕng dalěm.

Doewoehan (46) kandjĕng dalĕm "Ijeu maoeng dek dirĕpotkeun ka kandjĕng toewan rĕsiden Rĕmbang."

$\mathrm{Nja}$ koering njoehoenkeun widi moelang bae ka Panjatjaran.

Barang koering datang ka imah, ladjoe ngala maoeng di Tjikeusik. Sabot koering di Tjikeusik datang te koopen en een blik kruit. Ik begaf mij op weg vergezeld van vijf en twintig man en medenemende vier geiten benevens leeftocht, zooals rijst, olie, zout, tabak, ingredienten voor het betelkauwen en wat dies meer zij.

$\mathrm{Te} T \mathrm{~T}$ itĕngah aangekomen, stelden wij wĕlĕngs op; maar wij konden er maar é́n klaar krijgen, op de plaats waar de man vroeger door den tijger naar toe gesleept was. De drie nog overblijvende geiten werden gestald in het wachthuis Gawan; wat mij betrof, ik overnachtte in het gehucht $D j a d j a w a j$.

Den volgenden morgen ging ik naar den wĕlĕng kijken; toen ik mij verzekerd had, dat het schot was afgegaan, nam ik de meeste voorzichtigheid in acht; zie, zonder dat wij hem gewaar werden, hield de tijger blazend stand en brulde ons aan.

Toen ongeveer een keer of zes op hem gevuurd was, gaf hij weldra den geest; daarop werd hij gevild; de huid en de kop werden nog dienzelfden dag naar M ĕn es gebracht en aan den regent ter hand gesteld. De regent zeide: "Over dezen tijger zal ik rapport uitbrengen aan den resident van Rĕ $m$ bang."

Ik vroeg verlof om naar $\mathrm{Panja-}$ tjaran terug te mogen keeren.

Thuis gekomen, ging ik vervolgens naar Tjikeusik om daar tijgers te vangen. Terwijl ik mij te 
soerat ti Mĕnes, jen koering koedoe ka Mĕnes ngala pĕrsen maoeng. Sabalikna ti Mĕnes gantjang koering ngala maoeng di Tjikeusik deui. (47)

Barang dipasangan sakali, ĕmbe beunang koe maoeng, bĕdil beutoe, tapi maoengna mah teu beunang. Toeloej dipasangan deui, diberean loemat (48) kosong. Kira poekoel salapan sore bĕdil beutoe (49) serrta sora maoeng gěroeng gěroeng. Tapi teu aja noe wani noeroenan.

Barang isoekna koe koering ditejang, eta maoeng geus teu bisaeun leumpang, sabab potong balikatna, (50) tapi tatjan paeh.

Toeloej ditejang koe roerah (51) Minggoe, dibĕdil ti loehoer leuit tapi wĕleh teu daek paeh.

Tidinja koe koering dibĕdil tjangkengna, datang ka paeh.
Tjikeusik=bevond kwam er een brief van M ĕnes, dat ik mij daarheen moest begeven om de tijgerpremie te halen. Van Mĕnes teruggekomen, ging ik weder naar Tjikeusik om tijgers te vangen.

Toen de val voor de eerste maal opgesteld werd, nam de tijger de geit weg, het schot ging af, maar de tijger werd niet getroffen. Daarop werd de val nogmaals geplaatst zonder lokaas. Ongeveer tegen acht uur 's avonds ging het geweer af en de tijger brulde aanhoudend. Maar niemand durfde daarheen gaan. Toen ik den volgendeu morgen ging kijken, kon de tijger reeds niet meer loopen, omdat zijn schouderblad gebroken was, maar hij was nog niet dood. Vervolgens ging roerah $\mathrm{M}$ in ggoe naar hem kijken, hij schoot er op uit de schuur, maar te vergeefs, de tijger kon niet aan zijn eind komen. Toen schoot ik hem in de lendenen dood.

Ter vergelijking der spreektaal in $\mathrm{Zu}$ id-Bantĕn met het dialect der Preanger-Regentschappen heb ik het verhaal van Ki-A sdoera in de Preangertaal overgezet.

Aan den Heer S. Coolsma, die den Bijbel in het Soendaneesch vertaalde en vele jaren in dat gewest vertoefde, zij vooraf mijn oprechte dank gebracht voor de hulp mij bij de overzetting in het Preangersch geboden.

Ik heb zooveel mogelijk den gedachtengang en ook den zinbouw van den oorspronkelijken verhaler behouden; vandaar dat de stijl dikwijls stijf is.

Een Preanger Soendanees - en vooral een eigenaardig man als KiAsdoera - vertelt immers aanschouwelijk met eene menigte werkwoordelijke en gewone tusschenwerpsels en aardige zinswendingen. 
Om een goeden Preangerschen tekst te hebben, zou men eigenlijk hetzelfde verhaal moeten laten doen door een paninggaran uit die residentie.

Ik hoop evenwel, dat men mijne proeve voor lief zal willen nemen en dat ik daarmede - al zij het ook in geringe mate - mijn doel moge bereiken, namelijk om hier te lande de belangstelling op te wekken voor het ongelukkige B a n tĕn, dat in de laatste jaren zoo'n treurige vermaardheid heeft gekregen.

Asalna koering nampi timbalan djoeragan tjamat Moendjoel, jen koering kědah leumpang ka Panimbang; harita mĕnĕran dintĕn salasa, geus hilap boelanna sarĕng tanggalna.

Isoekna dintěn rĕbo bral koering leumpang ka Panimbang, ngabantoen djalma rejana gĕnĕp poeloeh, sarĕng hidji loerah, wasta poen Asdoera, nja eta anak koering.

Barang koering dongkap ka Panimbang, njampak djoeragan patih Tjaringin di boemi djoeragan wadana. (52)

Ladjĕng koering ngadeuheus ka djoeragan wadana sarĕng ka djoeragan patih.

Doepi timbalan djoeragan patih: "Ajeuna maneh, Bapa Asdoera, hade njijar baris mondok bae."

Seg koering mondok di masigit. Doepi isoekna dintěn kěmis koering diadjak leumpang ka Tjitěngah, ngiring djoeragan patih sarĕng djoeragan wadana. Ari djalma noe gĕnĕp poeloeh teja mah hĕnteu dibantoen, ditilarkeun di Panimbang bade ngadjaga di pakĕmitan.

Noe ngiring djoeragan patih mah ngan oepas-oepas bae.

Dintĕn harita ngan dongkap ka lĕmboer Djadjawaj, pĕrnahna sakalereun Tjitěngah. Ladjĕng ngarĕrĕb sawĕngi.

Di dinja njampak djoeragan tjamat Katoembiri sarĕng djoeragan tjamat Tjiseureuheun, njarandak pirang-pirang djalma, sami sajagi pakarang, sapĕrtos bĕdil, golok, toembak, bědog, balijoeng, patjoel sarĕng pakarang salijan ti dinja.

Isoekna dintĕn djamahat sadajana djalma arangkat ka pasir Hoeloe Gawan, sakalereun Tjitĕngah. Barang parantos koempoel sadajana di pasir Hoeloe Gawan, ladjĕng djoeragan patih miwarang meuleum mĕnjan ka hidji hadji wasta poen hadji Baris, tina pěrkawis rek njatjar di pasir Hoeloe Gawan bade ngadamĕl saoeng pasagi.

Saparantos eta hadji ngoekoes, ladjĕng sadajana djalma-djalma njalatjar lĕgana kintěn toedjoeh poeloeh toembak pasagi. 
Barang parantos njatjar pisaoengeun, djoeragan patih nimbalan ka djoeragan waılana, jen eta djalma-djalma kědah dibagi-bagi: bade ngala hoë opat poeloeh lima, ngala awi salapan poeloeh lima, ngala hateup opat poeloeh lima, ngala tjaï lima; sasesana ngarala kai bade piadjireun.

Ari noe ngala tjaï dimandoran koe hidji hadji, wasta poen hadji Tarminah sarĕng koe lěbe Bodjong Koneng.

Eta doewa djalma kenging milih.

Doepi noe ngala tjaï teja wĕleh, teu kenging tjaï, tina pĕrkawis disingsijeunan maoeng di djalan waktoe rek ngala tjaï di antara Tjitěngah sarĕng saoeng Gawan; ladjĕng maroelang deui bae, oendjoekan ka djoeragan patih sarĕng ka djoeragan wadana, jen maranehanana disingsijeunan maoeng.

Lahiran djoeragan patih: "Ajeuna montong ngala tjaï ka dinja; ka dijeu bae, ka kalereun saoeng Gawan mapaj djalan gěde."

Ladjěng ngarala tjaï ka dinja.

Barang djalma noe ngarala hateup geus dongkap, ngoeninga deui, jen maranehanana dipĕgatan maoeng; malah meh teu kenging hateup.

Doepi hoë, awi, hateup sarĕng kai parantos sadija, ladjĕng ngadamĕl saoeng.

Kintĕn wantji ngarangsang eta djalma noe keur ngadaramĕl saoeng disĕntakan maoeng bari gĕgĕroengan.

Gĕr bae djalma sakitoe lobana laloempatan, teu ngoeroes djoeragan wadana sarĕng djoeragan patih.

Anging koering pribadi noe masih aja di dinja.

Ladjĕng djoeragan patih miwarang koering ngadjaga ti wetaneun saoeng. Kakarek djalma-djalma waraniëun deui didaraměl.

Kintěn wantji těngari koering dipiwarang ngoekoes deui koe djoeragan patih; pek koering ngoekoes koeloneun djalan njanghareup ngoelon. Saparantos koering ngoekoes, bĕrkah, wiloedjĕng, teu aja kitoe-kijeu deui dongkap ka boerit. Noe didaramĕl sami djongdjon dongkap ka parantos eta saoeng.

Saparantos sadija eta saoeng, djoeng sadajana djalma-djalma arindit ngiring antĕnar-antĕnar moelih, sĕdja koelěm deui di Djadjawaj.

Ari koering leumpang toeroet sisi djalan bae, ngadjaga djoeragan patih sarěng djoeragan wadana.

Barang dongkap ka sisi lĕmboer Djadjawaj, loerah Tjigabig, wasta poen Saneh, leumpangna pangpajoenna.

Di dinja seg deui dipĕgatan maoeng, tanapi teu aja kitoe-kijeu; djalma-djalma kěbat bae ngaboedjĕng pamondokan ka Djadjawaj. 
Kintĕn wantji djam kadoewa wĕlas, tĕngah wĕngi, malěm saptoe, koeda djoeragan patih sarĕng koeda djoeragan wadana di kolong ngamoek teu kintĕn-kintĕn. Djalma sakitoe lobana taja hidji-hidji atjan noe waniëun toeroen.

Tidinja koering maksa maneh toeroen ngawaskeun eta koeda, koe naon sababna noe mawi ngamoek; nanging teu mĕndak naon-naon.

Barang isoekna, dintěn saptoe, isoek-isoek diilikan oeroetna, wĕt aja tapak maoeng ngintip koeda.

Parantos kitoe ladjĕng sadajana djalma-djalma ngiring djoeragan patih ngalih ka saoeng Gawan, bari ngabarantoen hateup bade ngahateupan saoeng Tjitĕngah.

Barang dongkap ka saoeng Tjitĕngah, pek njatjar deui sarĕng patĕpoeng sarĕng djoeragan wadana Tjibalijoeng.

Djoeragan patih ngabagikeun padamělan ka doewa wadana. Ari wadana Tjibalijoeng dibagian ngadamĕl doewa wĕlas kamar bade pangkoelěman toewan-toewan, ari wadana Panimbang dibagian ngadaměl bade pangkoelěman poetri sarĕng kangdjẹng pangeran, dapoer, djamban sarĕng istal.

Dintěn saptoe eta dangdosan parantos.

Teu lami deui ti saparantosna padamĕlan, soemping kangdjĕng toewan rĕsiden Rĕmbang, diiring koe djalma pirang-pirang. Ladjĕng paparijos $\mathrm{ka}$ djoeragan patih sarĕng $\mathrm{ka}$ djoeragan wadana, koemaha pětana hal ngala maoeng.

Doepi pioendjoek djoeragan patih: "Di dijeu, kangdjĕng toewan, teu aja noe jasa ngala maoeng, djabi ti Ki Asdoera."

Ladjĕng koering disaoer koe kangdjĕng toewan rĕsiden Rĕmbang. Saoerna: "Koemaha akalna ngala maoeng?" Pioendjoek koering: "Oepami aja maoeng ngahakan moending atanapi koeda, sok sĕring diwělĕngan."

Tidinja kangdjĕng toewan rĕsiden Rĕmbang ngatoer ngadamĕl ranggon doewa bĕlas, antjak doewa ratoes.

Barang parantos eta ranggon sarĕng antjak, soemping poetri, kangdjĕng pangeran, kangdjĕng toewan rĕsiden Bantěn, kangdjĕng dalĕm, sarĕng toewan toewan noe sanes, diiring koe antĕnar-antĕnar, loerah-loerah sarĕng pirang-pirang djalma.

Reup sore malěm ahad ladjĕng masangkeun ĕmbe sapandjang djalan, kalereun saoeng opat siki, kidoeleun saoeng lima siki.

Eta ĕmbe sawĕngi djĕpoet ditjangtjanganana.

Isoekna, dintěn ahad, eta ĕmbe noe salapan aja keneh sadajana. Malěm sěnen eta ĕmbe ditjangtjangkeun kidoeleun Tjitěngah 5e Volgr. VI. 
sakalereun Tjisoewakan. Didjaga koe poetri sasarĕngan sarĕng kangdjĕng toewan rĕsiden Rĕmbang.

Sakalereunana kangdjĕng pangeran sarĕng toewan-toewan noe sanes.

Aja deui doewa toewan noe ngadjaga di kidoeleun Tjisoewakan, di sasak Tjirambětoek.

Ari kangdjĕng dalĕm ngadjaga kalereun saoeng Gawan.

Harita eta ĕmbe noe hidji, nja eta noe pangkalerna, kenging koe maoeng.

Ari koering ngadjaga di Tjisoewakan sarĕng djoeragan, wadana Tjibalijoeng.

Teu lami bĕlĕdoeg sora bĕdil; kangdjĕng toewan rĕsiden Rĕmbang ngaloeloengsoer moelih ka Tjitĕngah.

Tidinja koempoel di Tjitĕngah, ngan toewan noe aja di Tjirambětoek tilar di dinja.

Ari djalma-djalma noe loba meutingna masing-masing bae: aja noe dina saoeng, aja noe di leuit, tina sabab teu tjĕkap ĕnggonna.

Kintẹn-kintěn těngah wĕngi malĕm sĕnen aja sora maoeng sarĕng sora djalma gagawokan.

Ana seg diboedjĕng koe djalma loba, njata jen aja hidji djalma, wasta poen Saiman, dibawa ti leuit koe maoeng.

Wĕngi harita keneh ladjĕng disoesoel, kintĕn gĕnĕp atawa dalapan toembak djaoehna teu kapěndak.

Tina perkawis teu kapěndak, kangdjĕng toewan rĕsiden Rŭmbang marijos ka koering: "Koemaha pikir, eta djalma geus djaoeh dibawana?"

Pioendjoek koering kantĕnan djaoeh.

Ladjĕng kangdjĕng toewan rĕsiden Rĕmbang moelih bae.

Tidinja bral sadajana ka pamondokan.

Harita di dinja teu kintěn roesoehna.

Parantos kitoe aja timbalan kangdjĕng toewan rĕsiden Rĕmbang, jen eta doewa toewan noe aja di Tjirambětoek kĕdah ditejang. Kangdjĕng dalĕm miwarang ka djoeragan patih sarĕng ka djoeragan wadana sarĕng ka tjamat-tjamat, nja eta tjamat Katoembiri, tjamat Moendjoel sarĕng tjamat Tjiseureuheun, sarĕng mantri oeloe-oeloe, nanging teu aja noe wani.

Tidinja eta tjamat-tjamat njaoer koering, dipiwarang nejang eta doewa toewan ka Tjirambětoek. Iadjĕng koe koering ditejang sarĕng tjamat-tjamat, sarěng ngabantoen djalma noe mawa obor, pada sadija pakarang, bĕdil, toembak sarĕng golok. Ladjĕng eta toewan-toewan moelih ka Tjitĕngah kaboedjĕng sijang dintĕn sĕnen.

Barang dongkap ti Tjirambětoek, sadajana djalma-djalma sarĕng 
toewan-toewan parantos njaroesoel djalma noe dibawa maoeng ka leuweung teja. Teu lami kapĕndak bangkena; ari noe parantos dihakan biritna, pingpingna sarĕng laranganana. Eta bangke diantĕp bae harita mah, tina pĕrkawis djalma-djalma pada njatjar ngadjaga maoeng. Eta ranggon disajagikeun ngaler-ngidoel. Ladjĕng kakarek digiring nganggo antjak; hidji antjak dibantoen koe dalapan djalma.

Noe ngatoer ngagiring kangdjĕng toewan koentroelijoer Goenoeng Kantjana, kangdjĕng toewan koentroelijoer Mĕnes, djoeragan patih, djoeragan wadana Tjibalijoeng, djoeragan wadana Panimbang sarĕng tjamat-tjamat.

Sami sajagi bĕdil, golok, toembak.

Nanging maoengna teu kapĕndak.

Doepi eta bangke ditjangtjang kana toenggoel, ditalian leungeunna.

Ari reup sore malěm salasa didjaga koe doewa toewan.

Kintěn wantji sareureuh eta maoeng datang, dibĕdil, nanging teu teurak. Jadjĕng kangdjĕng toewan rĕsiden njaoer koering, dipiwarang nejang kana eta sora bĕdil. Enggalna ditejang ka dinja. Barang parantos tetela jen teu teurak, koering balik deui bae.

Kintĕn-kintĕn wantji soeboeh koering ngiring kangdjĕng toewan rĕsiden Rĕmbang nejang eta toewan noe ngadjaga teja dina ranggon, ladjĕng moelih $\mathrm{ka}$ pondok.

Wantji beurang kangdjĕng toewan rĕsiden Rĕmbang ngĕrsakeun ningkĕran maoeng bade giringeun. Kapěndak oeroetna, malah karoengoe sorana. Ladjĕng digiring deui sakoemaha tadi, nanging maoengna mah teu kapĕndak. Tidinja digiring sakali deui, lĕpat deui.

Ari reup wěngi malěm rĕbo eta bangke ditoenggoe deui, ditambahan ĕmbe dalapan siki. Nanging wĕngi harita hĕnteu aja noe datang.

Isoekna dangdos sajagi moelih; kintĕn poekoel dalapan bral angkat, moelih ka Panimbang, ladjĕng ka Mĕnes, diiring koe menakmenak, loerah-loerah sarĕng djalına-djalma.

Antawis dalapan dintěn ti mangsa harita koering kenging parentah ti dajeuh, kĕdah ngala maoeng ka Tjitĕngah, dipaparin artos dalapan roepijah bade ngagaleuh ĕmbe sarĕng obat satjarak. Bral koering leumpang ngabantoen djalma salawe, ěmbe opat siki sarĕng pisangoeëun, sapěrtos bejas, minjak, oejah, bako, lëmareun sarĕng salijan ti dinja.

Barang dongkap di Tjitěngah, ladjĕng ngadangdanan welĕng, nanging ngan kaboedjĕng ngadamĕl hidji di oeroet djalma noe dibawa koe maoeng teja. 
Ari ĕmbe noe tiloe deúi diteundeun di saoeng Gawan, ari koering ngaboedjĕng mondok ka lĕmboer Djadjawaj.

Ari isoekna eta wělĕng ditejang. Barang parantos tetela, jen eta bědil beukas, koering ati-ati. Bět teu kanjahoan deui, eta maoeng. sĕgor bae, mogok bari njĕntakan. Tidinja djĕdor dibĕdilan kintěn gĕnĕp kali; teu lami eta maoeng paeh. Ladjĕng dirasah; koelitna sarĕng hoeloena dibantoen ka Mĕnes dintěn harita keneh sarĕng disanggakeun ka kangdjĕng dalĕm.

Dawoehan pangawoelaän: "Ijeu maoeng dek disanggakeun ka kangdjĕng toewan rĕsiden Rĕmbang."

Tidinja koering njoehoenkeun widi moelang ka Panjatjaran.

Saparantos dongkap di rorompok, ladjĕng leumpang ngala maoeng ka Tjikeusik. Sabot koering di Tjikeusik, datang sĕrat ti Mĕnes, jen koering kĕdah ka dajeuh, nampi pěrsen maoeng.

Sadongkapna ti Mĕnes enggal koering balik deui ka Tjikeusik. Barang dipasangan wělĕng sakali, ĕmbe kenging koe maoeng, bĕdil bitoe, nanging maoengna teu kenging.

Ladjěng dipasangan deui, diëupanan eupan kosong.

Kintěn poekoel salapan sore bědil bitoe. Kadenge sora maoeng gĕrang-gĕroeng. Nanging teu aja noe wani nejang. Isoekna ditejang koe koering; eta maoeng geus teu kadoegaeun leumpang, wireh potong walikatna, nanging tatjan paeh.

Ladjĕng ditejang koe loerah Minggoe, dibědil ti loehoer leuit, wěleh teu daekeun paeh. Tidinja koe koering dibĕdil tjangkengna, hos paeh. 


\section{A A NTEEKENINGEN}

(1) Vroeger vond het praedicaat $\mathrm{ki}$ eene ruimere toepassing dan tegenwoordig. De kleine man sprak steeds van ki-patih, kiwadana, ki-mantri.

Thans, nu men zooveel mogelijk de Preangersche adat tracht na te volgen, is het door djoeragan of soms voor de lagere ambtenaren door madjikan vervangen en zegt men djoeragan patih, djoeragan wadana, djoeragan mantri of madjikan mantri, madjikan djoeroetoelis.

$\mathrm{Ki}$ wordt slechts gebruikt ten opzichte van bejaarden en van geestelijken: ki-Asdoera, ki-Entjim, ki-hadji Doelgani, ki-pangoeloe Padarame (de desa-geestelijke van Padarame), ki-pangoeloe landerrat (de pangoeloe bij den landraad).

(2) In het Preanger-dialect dong ka p.

(3) De toenmalige patih van $\mathrm{Tjaringin}$ is onder-collecteur te Rangkas-bitoeng geweest en heeft zich steeds beijverd om het beschaafder dialect der Preanger Regentschappen aan te leeren en te spreken.

Het woord pamondokan heb ik nooit in den mond van het volk gehoord. Gewoonlijk bezigt de kleine man de uitdrukking tĕmpat meuting of pasanggrahan.

Mondok wordt in den regel slechts gebruikt in den zin van ergens of bij iemand tijdelijk inwonen, speciaal om de lessen aan eene pasantren of bij een vermaarden goeroe te volgen.

Vraagt men in de desa naar iemand en bekomt men bijv. tot antwoord: "keur mondok di Koempaj" - dan wil het niet zeggen, dat de persoon in kwestie te Koempaj bij den een of anderen voor zijn genoegen uit logeeren is, maar dat hij daar godsdienstonderwijs erlangt.

(4) In het Preanger-dialect pakĕmitan.

(5) Het woord baris, dat oorspronkelijk beteekent: lijn, streep, rij, gelid, slagorde, krijgsvolk, legerschaar, leger, op eene rij staan, bv. knoopen; in orde geschaard staan, opgesteld zijn, van militairen, (zie Soendaneesch-Hollandsch woordenboek door S. Coolsma) wordt 
in Zuid-Bantĕn bovendien gebruikt als een hulpwoord om een zeker aantal personen van dezefde categorie aan te duiden. Zoo zegt men, behalve baris oepas - de oppassers -, nog baris djaro - , een onbepaald aantal desahoofden - , baris parajai de inlandsche ambtenaren, baris kolot - de oudsten in de desa, die bij gewichtige gelegenheden geraadpleegd worden, enz. $(*)$

Het doet in die gevallen denzelfden dienst als para.

Zie de Inleiding van boven genoemd woordenboek $\S 69$.

(6) Onder lĕmboer verstaat men eene verzameling huizen, die bij elkander hooren en als het ware een geheel vormen. Het kan eene op zich zelf staande gemeente zijn, dan wel een deel daarvan uitmaken.

Eene desa is daarentegen de jurisdictie eener gemeente, hetzelfde als kadjaroan, het gebied waarover een $d j a$ ro gezag voert.

Bijna alle desa's van $\mathrm{Zuid-Bantĕn} \mathrm{bestaan} \mathrm{uit} \mathrm{twee} \mathrm{en} \mathrm{meer}$ gehuchten - lĕmboer of a mpijan - die soms ettelijke palen van elkander liggen, waardoor het rechtsgebied eene groote oppervlakte beslaat.

Zoo heeft de Tjilangkahansche desa Tjibareno bijna dezelfde uitgestrektheid als het geheele district Tanara, een onderdeel van het Noorder-Regentschap.

(7) Antero is een verbastering van het Bataviaasch-maleische انتيرو ĕntero (van het portugeesche inteiro) gansch, geheel het gansche enz. In het Preanger dialect: $\mathrm{sakabeh} \mathrm{k}$ en sadaja $\mathrm{l}$.

Dat in het Zuid-Bantĕnsch tal van Bataviaasch-maleische woorden burgerrecht hebben gekregen, moet ons niet verwonderen. Na affoop van den padioogst trekken jaarlijks honderden Zuid-Bantěners naar Batavia om er zich als koelie te verhuren.

(8) Pamatang Hoeloe Gawan. Deze heuvelrug is genoemd naar den oorsprong - hoeloe - van het stroompje - tjileungtjang - Gawan. Later zullen wij zien, dat de verhaler van het daar gebouwd wachthuis sprekende, telkens zegt: goeboeg Gawan.

(9) Toeloej djoeragan patih miwarang ka hidji

$\left.{ }^{*}\right)$ In de «Badoejsche pantoenverhalen», opgenomen in eene vorige aflevering van dit tijdschrift komen deze voorbeelden voor van het gebruik van baris: in de lalakon Raden Tĕgal: "papatihna Praboe Koeda Kantjana, linggihna di babalean, lengreng baris ponggawa di babalean» en: akatjaritakeun baris pawistri tjalik di padalěman.» (pag. 59.)

Baris heeft ook de beteekenis van: tot, dienen tot; geheel gelijk aan poerah. Zoo o. a. in den Preangerschen tekst: «Ajeuna, maneh Bapa Asdoera, hade njijar baris mondok bae.» 
hadji, ngaran hadji Baris, meuleum mĕnjan tina sabab dek njatjar di pamatang Hoeloe Gawan - de patih gaf last aan een hadji, hadji Baris genaamd om wierook te branden, omdat men een stuk van het bosch op den heuvelrug Hoeloe Gawan wilde wegkappen.

In het Zuider-Regentschap - en misschien elders ook — bestaat de gewoonte, dat men wierook of eene andere reukstof - kajoe hagaroe, akar djamaka, geutah rasamala, - brandt onder het uitspreken van een djadjawokan of djampe, alvorens een begin te maken met het wegkappen van het geboomte.

Die formaliteit, welke verricht wordt door een persoon, bekend met het bezweringsformulier, heeft plaats bij het aanleggen van een hoema, een weg, het openkappen van het terrein voor eene nieuwe lĕmboer.

(10) In het Preanger-dialect k a i.

(11) Hadji Tarminah. Tarminah is een vrouwennaam en het zal daarom menigeen verwonderen, dat die gedragen wordt door een man.

Wij weten, dat op Java de gewoonte bestaat om iemand, die kinderen heeft, naar den oudsten zijner nakomelingen te noemen met bijvoeging van bapa of pa - bij de Badoejs ajah - voor den vader en ma, bok of ĕmbok, a mboe, iboe voor de moeder - annan nagaml der Javanen.

Tjitrå zal bijv. na de geboorte van zijn Gĕnțo door zijne desagenooten pak Gĕnṭo genoemd worden.

In Zuid-Bantĕn daarentegen verdwijnt de oorspronkelijke naam geheel en krijgen de ouders dien vau hun eersteling in de plaats, zelfs al is deze in zijne eerste levensjaren overleden.

Dit gebruik verklaart, waarom men in de desa tal van mannen aantreft, die een vrouwen naam dragen. Zoo herinner ik mij, dat de djaro der desa Badoer - bekend uit Multatuli's Max Havelaar als de woonplaats van Saidjah en Adinda - volgens zijne acte van aanstelling Sarilah heette. Zijne ambtgenooten van Rahong en Sawarna stonden in de officieele registers bekend als $\mathrm{M}$ inah en Djä̈.

Het gebeurt ook, dat dezelfde persoon in twee desa's verschillende namen draagt. Mijn staljongen werd in de desa, waar hij na zijn huwelijk gewoond had, naar zijn eerste kind Taïrin genoemd; in de desa Padarame, waaronder de standplaats van den in de afdeeling Goenoeng Kantjana bescheiden kontrôleur sorteerde, 
kende men hem alleen onder den naam Tarisah, naar zijn op het erf der kontrôleurswoning geboren dochtertje.

In Bantěn volgt men de school (madshab) van asj-Sjâ fe'î en de Bantĕnsche pelgrims krijgen dan ook, nadat zij de formaliteiten der bedevaart hebben in acht genomen, van den ima m der Sjâfe'ieten - imam sapingi - een naam.

Men zou van de als streng in de leer bekend staande Bantěners verwachten, dat zij veel waarde hechtten aan dat Mekkaansch geschenk en na hunne terugkomst in hunne desa's zich bij voorkeur bij dien pelgrimsnaam lieten noemen. Dit is echter niet het geval.

Een gewezen djaro van Tjiboengoer (district Lĕbak) ontving van den imam der Sjâfe'ieten den naam van Moehammad'Alî.

Eens informeerde ik in die desa naar hadji Moehammad'Alî; niemand wist mij een antwoord te geven. Eerst toen ik als toelichting er bij verteld had, dat hij desahoofd geweest was, zeide men, dat ik dan zeker hadji Padja bedoelde.

De meeste hadji's waren hunnen pelgrimsnaam vergeten. Wanneer men de nominatieve staten voor het hoofdgeld in het archief te Goenoeng Kantjana naslaat, zal men onder de getulbande aangeslagenen vinden: hadji Baragadjoel, hadji Saripah, hadji Peutjang, hadji Komboj, - voorwaar geene gewijde namen.

Ter voorkoming van verwarring en ontduiking van belastingen en heerendiensten hebben de regent van het Zuider-Regentschap en ik getracht eene verandering teweeg te brengen in die adat.

Onze pogingen werden evenwel met geenen gunstigen uitslag bekroond.

(12) Pangoeloe is in Bantĕn in de eerste plaats hetzelfde als in de Preanger Regentschappen panghoeloe.

In de tweede plaats is het de titel van den desa-geestelijke, lid van het desabestuur, die ook wel amil (van het arabisch ل⿺辶 verrichter, bestuurder, rentmeester, ontvanger,) genoemd wordt.

Zie aangaande zijnen werkkring: "Resumé van het bij Gouvernements besluit van 10 Julij 1867 No 2 bevolen onderzoek naar de regten van den Inlander op den grond in de residentie Bantam, zamengesteld door den Chef der afdeeling Statistiek ter Algemeene Secretarie" pag. 8 en volg. $\left({ }^{*}\right)$

${ }^{*}$ ) In de Preanger Regentschappen voert hij met uitzondering van het regentschap $\mathrm{Tjiandjoer,} \mathrm{waar} \mathrm{hij} \mathrm{ook} \mathrm{amil} \mathrm{genoemd} \mathrm{wordt,} \mathrm{den} \mathrm{titel} \mathrm{van}$ lĕbe. Zie Coolsma sub voce.

In de districten Boemiajoe en Salěm van het Regentschap Brěběs (residentie 
(13) Goeboeg. In Midden Java marym . Hetzelfde als sao eng in het Preanger dialect.

(14) Gĕr bae djělěma sakitoe lobana la loempatan, teu ngoeroes ngoeroes djoeragan wadana atawa djoeragan patih. Allen gingen op den loop en zagen in het geheel niet om naar den patih of den wadana.

Deze onverschilligheid lijkt wel vreemd; niet licht toch zullen de inlanders, vooral wanneer zij zoo sterk in getal zijn, hunne hoofden aan hun lot overlaten.

Ik wil geenszins beweren, dat de Zuid-Bantĕners laf van natuur zijn uitgevallen, maar de tijgervrees is bij hen al bijzonder sterk ontwikkeld.

Et pour cause.

In den laatsten tijd hadden de zuidelijke districten van het Wester-Regentschap (de afdeeling Tjaringin) veel van deze roofdieren te lijden. Jaarlijks werden van vijftig tot zestig personen door hen gedood.

Geheele desa's liepen leeg en de inwoners zochten in de meer veilige noordelijke districten of in het aangrenzende Zuider-Regentschap een goed heenkomen.

De premie op het vangen van koningstijgers werd van $f 30$ eerst tot $f 100$ en later tot $f 200$ verhoogd. Het bestuur hoopte op die wijze onversaagde jagers van elders naar het zuidelijk deel van Tjaringin te lokken om de bevolking van die plaag te verlossen. Door die verhuizingen en masse raakten het district $\mathrm{Tjibali-}$ joeng en het zuidelijk deel van Panimbang geheel ontvolkt.

De kleine man zelf gaf zich weinig moeite om het roofgedierte uit te roeien. Dit was een gevolg van het bijgeloof. Men meende namelijk, dat het geene gewone tijgers waren, maar maoeng kadjaden, eene metempsychosis der voorouders - (loeloehoer Bantĕn).

De bewoners der geteisterde streken trachtten door offeranden en bezweringen de verbolgen geesten weder gunstig te stemmen. Eerst

Tĕgal) heeten zij agๆ vangen; plaatsvervanger; vicaris ; vice.

Zoo heeten ook de tot het sluiten van huwelijken bevoegde vervangers van den




met het afroepen van den aanvang der tijden voor de versohillende gebeden (أذاب) 
wanneer een tijger een mensch, paard of karbouw had aangevallen, besloot men een val-wĕlĕng, pigasol, pigĕboeg, biraloek, boerang, tjara, pitangk ěb, - te plaatsen om hem te vangen.

(15) In het Preanger-dialect wetanna.


midden van den dag, wanneer de zon juist in het zenith staat dus

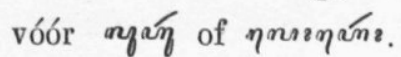

In de Preanger-Regentschappen gebruikt men daarvoor de uitdrukking tĕngah poë of het Bataviaasch-maleische tĕngari verbastering van het maleische, تُّنَها t ĕngng a h hari.

(17) In het Javaansch het ngoko woord van mo: In het Preanger dialect, toeloej k en ladjĕng $\mathrm{l}$.

(18) In het Preanger-dialect koeloneun.

(19) In het Preanger-dialect njanghareup.

(20) Kira kira wantji tangange koering dipiwarang ngoekoes deui koe djoeragan patih. Ladjoe koering ngoekoes barateun djalan, ngahareup ka barat. Ongeveer tegen twaalf uur gelastte de patih mij om weder wierook te branden. Toen ging ik wierook branden, ten westen van den weg met mijn aangezicht naar het westen gekeerd.

De Bantĕners, hoewel behoorende tot het meest mohammedaansch gedeelte der bewoners van $\mathrm{J}_{\mathrm{a}} \mathrm{va}$, zijn in hooge mate bijgeloovig en dientengevolge bezitten zij een schat van djampe's of djadjawokan's.

Dat Ki-Asdoera die opdracht van den patih kreeg, is begrijpelijk. Hij toch stond bekend als de moedigste tijgerjager in $\mathrm{Zuid}$ Bantĕn, die gedurende zijn leven meer tijgers gedood en gevangen heeft dan er aanwezig zijn in de verschillende diergaarden van Nederland te zamen.

- Zijn voortdurend succes heeft dan ook gemaakt, dat men hem het bezit van geheime en wonderkrachten toeschreef, die hem telkens in zijn strijd tegen tijgers de overwinning deden behalen.

Niettemin wilde hij nooit voor doekoen maoeng (tijgerbezweerder) fungeeren en beweerde steeds, dat de beste toembal (bezweringsmiddel tot afwending of tot bevrijding van geesten, plagen enz.) een puntkogel - pelor djantoeng - was.

Dat belette echter niet, dat hij even als alle andere Zuid-Bantěnsche paninggaran's van djampe's gebruik makte.

Als merkwaardigheid laat ik hier een paar der in die streken meest bekende jagerstooverspreuken, die hij mij geleerd heeft, volgen: 
"Bismillâh ar-rahmân ar-rahîm (uitgesproken als: bismillah kĕrakman kĕrakmin) sang oegĕràn djatingaranning bĕdil. Sang prĕngok djati ngaranning obat. Sang koelintir poetih ngaranning pelor. Soet soet parasoet papagèna goestinira $\mathrm{Dj}$ anoerwenda. $\mathrm{Ija}$ ikoe papangannira boeloe, koelit landaging. Inoem-inoemannira gĕtih. Dadalannira oerat. Kasograännira soengsoem lan baloeng. Sĕwarganira ing djadjantoeng. Ija ikoe papangannira oentjal."

Een tweede luidt: "Poen, poen, poen, moel koekoesaïng tendjo maja, leko maja; a ing ngatoeran sangoekoekoes sapoeloekanka danjang di dijeu; ka noebadag, kanoe aloes; aïng menta maoeng."

Een derde: "Agaloenda agalindoe, hoeloe batoe koesimpaj, simpaj batoe koe hoeloe, tjahlaj tjahlaj tjahlaj."

(21) Het woord bĕrkah van het arabisch بركة zegen, geluk, voorspoed, is als het ware bestorven in den mond van een ZuidBantěner. Elk bevestigend antwoord begint er meê. Het staat dus in 't gebruik gelijk met ons "dank U" en het Duitsche "Bitte".

Vraagt men aan een djaro of hij zijne landrente aangezuiverd heeft - "bĕrkah, ěnggeus loentak" - ja, zij is afbetaald zal hij zeggen.

Komt men in een gehucht en informeert men naar den gezondheidstoestand der inwoners: "koemaha didijeu, euj, tjalalagĕr kabeh?" - zeg, hoe is het, zijn allen hier gezond? - uit één mond klinkt het: "bĕrkah, ěnja tjag ĕr" - ja, gezond.

Een desahoofd laat zich aandienen, na zijn arrest op de pantjaniti (*) te hebben ondergaan. "Koemaha, djaro, sorangan geus ngadjalankeun hoekoeman?" - hoe is het, djaro, hebt ge uwe straf reeds ondergaan? - wordt hem gevraagd. "B ĕrkah, anggeus" - ja, bereids - zal hij antwoorden.

Soms wordt het uitgebreid tot "běrkah doa gamparan" of "bĕrkah doa adjĕngan" - tengevolge van uwe heilbede -



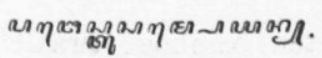

Zelfs de inlandsche ambtenaren bedienen zich van dat woord,

(*) Onder pantjaniti verstaat men hetzelfde als babantjong in de


Java. 
waar het te pas komt, wanneer zij met hunne europeesche superieuren maleisch spreken.

(22) Rengse: af, afgedaan, gereed, afgemaakt. Javaansch nвa-j.

In het dialect van het district- $\mathrm{Sal}$ ĕ $\mathrm{m}$, dat veel overeenkomst heeft met het Tjirěbonsch, zegt men daarvoor parele.

(28) Parajai of Prijaji beteekent tegenwoordig hetzelfde als het woord बंanain in het gouvernementsgebied van Midden-J a va: ambtenaar, beambte.

De beteekenis door Coolsma opgegeven: persoon of personen met het overbrengen of bezorgen van brieven belast, brievenbesteller is in $Z u$ id-Bant ěn niet bekend.

Zoo'n persoon heet daar pasoeratan. 1

Ouden van dagen konden zich nog herinneren, dat tijdens het bestuur van Raden Adipati Karta Nata Nagara, een der dramatis personae uit Multatuli's Max Havelaar, zóó genoemd werden de dienaren van den regent, die in de Preanger-Regentschappen den titel voerden van goelang goelang. Zie Coolsma sub voce.

(24) Zie de aanteekening bij lĕ $\mathrm{m}$ boe r.

(25) $\mathrm{Ng}$ amoek zegt men ook van dieren, die groote onrust aan den dag leggen, zonder dol te zijn, zooals paarden en rundvee, wanneer een tijger zich in hunne nabijheid bevindt.

Dan past men het woord nog toe op personen, die ijlen.

(26) In het Preanger-dialect pasarean.

(27) Papariksa, van het grondwoord pariksa, beteekent

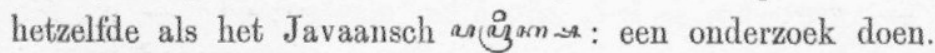

(28) $\mathrm{N}$ gawĕlĕngan: een dier, bijv. een tijger door middel van een wĕlĕng vangen.

Op welke wijze dit geschiedt, vindt men beschreven in mijne: "Bijdrage tot de kennis van het Bantěnsch dialect der Soendaneesche taal" en in het Tijdschrift voor het Binuenlandsch Bestuur van 1888, Dl. II, afl. 3 pag. 186 en volg.

(29) Deze ranggon's die eerder den naam van panggoeng verdienden, waren verplaatsbaar en dienden tot schuilplaats aan de schutters.

(30) Deze antjaks waren ramen van gespleten bamboe, twaalf voet lang en zes voet breed.

Hoe men ze bij de jacht gebruikte, zal straks beschreven worden. (31) De hier bedoelde Prins en Prinses waren Hunne Koninklijke

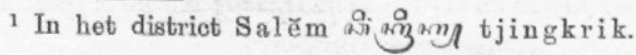


Hoogheden Henri, Charles, Louis, George, Abraham, Paul, Marie de Bourbon, Infant van Spanje, Prins van $\mathrm{P}$ arma, Plaisance en Guastalla, Graaf van Bardi, jongste, zoon van. wijlen Karel III, laatsten Hertog van Parma, en zijne gemalin Adelgonde de Jésus Marie de Bragance, Infante van Portugal, dochter van wijlen don Miguel, Koning van Portugal.

Zij waren vergezeld van de Graven Henri Lucchesi Palli en Alessandro Zileri dal Verme en Baron Detlev von Heijdebrandt.

De Nederlandsch-Indische regeering had dezen hoogen bezoekers als cicerone toegevoegd den houtvester der le klasse bij het boschwezen J. G. Baron von Hertling.

Het jachtgezelschap bestond verder uit de heeren E. A. Engelbrecht, resident van Bantĕn, H. L. Ch. Te Mechelen, resident ter zee, den op $\mathrm{J}$ ava algemeen bekenden tijgerjager, door $\mathrm{Ki}$ Asdoera, angeduid als kandjĕng toewan rĕsiden Rĕmbang, omdat Rĕmbang zijne standplaats was, Raden Toem ĕnggoeng Koesoemaningrat, regent van het Wester-Regentschap, R. J. Maas, kontrôleur van Tjaringin, H. de Chauvigny de Blot, kontrôleur van Serang en schrijver dezes, toeumaals kontrôleur van Goenoeng Kantjana.

(32) Van den regent sprekende zegt de kleine man meestal kandjĕng dalĕm (dalěm = daleum in het Preanger dialect) of adjĕngan dalĕm.

Hier en daar hoort men ook pangaw oeläa - zie bij Coolsma onder kawoela - een gevolg van Preangerschen invloed.

(33) Dit is de meest eenvoudige manier om op tijgers te jagen. Men bindt eene geit aan eenen stevigen paal, zoodanig dat het dier niet gemakkelijk door een tijger weggevoerd kan worden, en blijft den nacht in een nabijzijnden boom doorbrengen.

Ontdekt de tijger de geit, dan wil hij zich van haar meester maken en stelt den jager in de gelegenheid om op hem te schieten.

Het geduld en de wilskracht van hem, die deze methode van jagen in toepassing wil brengen, worden wel op eene zware proef gesteld. Men moet dagen achtereen den geheelen nacht wakker blijven - en gewoonlijk zonder resultaat.

Tijdens mijn verblijf te Goenoeng Kantjana heb ik menigmaal mijne nachtrust opgeofferd; toch is het mij nooit mogen gelukken op die wijze eenen tijger te dooden. 
(34) Njata jen aja djĕlĕma koe maoeng: kreeg men zekerheid, dat een man door een tijger was weggehaald. Het weglaten van het werkwoord dibawa is hier geene schrijffout. Wij zien dat de spreker het consequent doet. Iets verder lezen wij "nja roesoel noe koe maoeng ka leuweung" en "di oeroet djělĕma noe koe maoeng."

In identieke gevallen verzwijgt men meestal het werkwoord. Ik herinner mij nog de volgende voorbeelden:

manoek djapati noe koe heulang, de duif, die door een kiekendief aangevallen is geweest;

bapana noe koe boehaja, de vader van hem, die door een krokodil gedood is;

tangkal kalapa noe koe gĕlap, de klapperboom, die door den bliksem getroffen is;

aja taloe djĕlĕma koe oraj, er zijn drie menschen door eene slang gebeten.

(35) Dikwijls is beweerd, dat een tijger, die eenmaal menschenvleesch heeft geproefd, in den vervolge daaraan de voorkeur geeft boven alle andere voedsel. Vandaar dat hij bijzonder kwaadaardig schijnt en zich altijd laat zien dár, waar hij menschen op zijn weg kan ontmoeten.

Een Engelsch tijgerjager, die in Noord Borneo deze roofdieren heeft bestudeerd, noemt zoo'n tijger een man eater.

Het gebeurde op kerstavond van het jaar 1887 levert weder een bewijs voor dat beweren.

De bewuste tijger heeft den weg gevolgd, waar langs de geiten als lokaas gereed gezet waren.

Hij liet echter allen ong e moeid, drong het gehucht Tjit ěng a h, waar ongeveer vier honderd koelies gehuisvest waren, binnen en voerde een van hen, die met nog twee anderen in eene ledige schuur een onderkomen had gevonden, weg.

(36) Tĕritoeng is het maleische ترهيتع tĕrhitoeng. Het Soendaneesch daarvan luidt kaïtoeng of dïtoeng.

(37) Roesoeh heeft hier ongeveer dezelfde beteekenis als haliwoe en gandeng. Verder beteekent het nog: opstand, ongeregeldheden in een land.

Zoo zegt het volk steeds roesoeh Tjilĕgon, wanneer het van de gebeurtenissen op den 9n Juli 1888 in de afdeeling A njar spreekt.

(38) In het Preanger-dialect kakarek. In de taal der Badoejsche pantoens kakarak. Zoo o. a. in de lalakon Ranggah Sena: 
"Pawarangna tatjan deuk loba, kakarak boga dalapan, ngamitkeun toewang kakasih pawarangna.

(39) Een tijger, die zich van een mensch of dier heeft meester gemaakt, zal een gedeelte daarvan verslinden en het overschot bewaren voor den volgenden avond. Des daags zoekt hij zich eene schuilplaats in de onmiddellijke nabijheid van zijne prooi.

Deze gewoonte der tijgers wees ons den weg, hoe wij de drijfjacht houden moesten.

Daar het dien nacht (kerstnacht van 1887) zwaar geregend had, konden wij gemakkelijk het spoor van het roofdier volgen en ten naastenbij bepalen, in welk gedeelte van het bosch het een leger had gevonden.

Daar kapten de koelies eene strook van ongeveer 25 meters breedte en een half kilometer lengte open, waar de verplaatsbare ranggon's of panggoeng's op ongeveer vijftig meter afstands van elkaar opgesteld werden.

Deze ranggon's, circa 10 meter hoog, boden eene veilige schuilplaats aan de schutters, die bovendien een goed gezicht hadden op het opengekapt terrein, waarheen de tijger opgedreven zoude worden.

Hierboven zeide ik, dat de tijgervrees (ka sima) $\left(^{*}\right)$ bij de ZuidBantĕners bijzonder ontwikkeld was. Voor geen geld zouden zij daarom als drijver dienst willen doen.

Zij, die eene tịgerjacht hebben bijgewoond, zullen wel weten, dat men deze dieren bijna op hun staart moet trappen, alvorens zij over dag hun leger verlaten, - vandaar dat het opdrijven steeds met groot gevaar gepaard gaat.

Ik zelf heb dit ondervonden.

$\left(^{*}\right)$ In Zuid-Bantěn wordt het woord kasima bijna uitsluitend toegepast op menschen en dieren, aan wie door een tijger vrees is aangejaagd. Ik geloof echter niet, dat men het grondwoord daarvan in verband moet brengen met

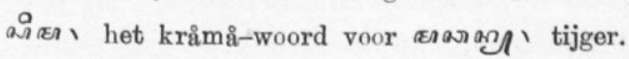

Volgens den heer Coolsma beteekent sima in het Soendaneeseh: "dat wat aan een mensch of dier te vreezen is of vrees aanjagt an een ander; $\mathrm{njima}$ beteekent vrees aanjagen; eerste passive vorm disima, tweede passive vorm kasima: door vrees bevangen.

Bij gelegenheid van een onderzoek in eene desa der afdeeling Go en o eng $\mathrm{K}$ antjana trachtte $\mathrm{ik}$ te vergeefs een der aanwezige desalieden aan het praten te krijgen. Op mijne vraag aan den betrokken djaro wat hem scheelde, ontving ik het antwoord: "Kasima koe adjĕngan.» Na afloop der vergadering ontving deze van den wadana eene ernstige vermaning, omdat die uitdrukking ten opzichte van den kontrôleur geheel misplaatst was. 
In Juni 1888 werd mij gerapporteerd, dat een bijzonder groote koningstijger in de nabijheid der onderdistrictshoofdplaats Goe noeng Kĕndĕng (district Tjilangkahan) een paard van een aldaar wonenden hadji had aangevallen en dat hij voortdurend in den omtrek bleef.

Een poging om hem met een wĕlĕng te vangen mislukte.

Vergezeld van de wadana's van Paroeng Koedjang en Tjilangkahan, benevens van een vijftiental der moedigste inwoners van Goenoeng Kĕndĕng en aangrenzende ampijan's, besloot ik jacht op hem te maken.

Een regenachtige nacht stelde ons in de gelegenheid on den daarop volgenden morgen het spoor te volgen.

Twee Zuid-Bantěners moesten telkens het kreupelhout wegkappen om een weg voor ons te banen.

Niets verried hun de nabijheid van den tijger, toen deze onverwachts met een gebrul opvloog en hen onder het uitroepen der gebruikelijke spreuk: "a' oeds Billâh min asj Sjaitân ar radjîm" — ik neem mijn toevlucht tot Allâh tegen Satan den gesteenigde meer dood dan levend achteruit deed stuiven.

Langzaam kromde hij zijnen rug om den sprong naar mij te dōen; veel tijd had ik niet meer om mij te bedenken, de afstand, die hem van mij scheidde, bedroeg nog geen tien passen. Schielijk legde ik mijn mousqueton-Mylonas aan en joeg hem een kogel in den kop, tusschen de beide oogen, - misschien wel de meest kwetsbare plek van zijn lichaam.

Doch om weder op de jacht te Tjitĕngah terug te komen.

De antjak's werden naar de plek, waar men meende dat de tijger zich ophield, gedragen.

De drijvers stonden op eene rij en op een gegeven teeken lieten zij ze voorover vallen, gingen er op staan, namen ze weder op en herhaalden - al voortgaande - deze handeling, totdat zij aangekomen waren aan den rand der opengekapte strook.

Op die wijze moesten alle wilde dieren - groot en klein die zich in dat deel van het bosch bevonden, opgejaagd worden, terwijl in geval een tijger zich op de drijvers werpen wilde, hunne met geweren gewapende aanvoerders hem zouden neerschieten.

(40) Dit is door $\mathrm{Ki}-\mathrm{As}$ doera onjuist verteld.

$\mathrm{Z}_{\mathrm{ij}}$, die in streken hebben gẹwoond, welke van tijgers wemelen zooals Zuid-Lĕbak, Zuid-Tjaringin, Poerwådadi (residentie Samarang) zijn ongetwijfeld bekend met eene eigen- 
aardige gewoonte dier roofdieren, waardoor men in staat wordt gesteld, om hen op eene vrij gemakkelijke nijze te vangen, zoodra zij ergens een karbouw of paard hebben weggehaald.

Zij zullen namelijk ten allen tijde bij hunne prooi terugkomen, waar zij die gelaten hebben.

Op deze gewoonte berust het plaatsen van vallen of het werken met bedwelmende en vergiftige bestanddeelen, waaronder de walikambing (Sarcolobus Spanogheï Miq. Nat. fam. der A sclepiadeae) vooral vermelding verdient.

Het lijk van Saiman werd op de plek, waar men het den volgenden morgen vond, begraven. Op het graf bond men eene der medegebrachte geiten en richtte daarbij een ranggon op, waarin de heeren Alessandro Zileri dal Verme en Detlev von Heydebrandt plaats namen.

De tijger stelde de algemeene verwachting niet te leur. Omstreeks zeven uur kwam hij bij de bewuste plek en gaf zijn aanwezen door een lang gegrom te kennen. Ongelukkig raakte de electrische lamp, eigendom van den heer $\mathrm{Te} \mathrm{Mechelen}$, waarmede de jagers het terrein op het oogenblik dat zij schieten zouden, verlichten moesten, onklaar. Twee schoten knalden in de duisternis, doch de expansive kogels misten hun doel.

Hoewel hij dien nacht herhaalde malen terugkeerde, vertoonde hij zich niet op het opengekapt gedeelte en bleef dus buiten schot.

Ik herinner mij op dit oogenblik niet meer, hoeveel koningstijgers de bevolking der kontrôleafdeeling Goenoeng Kantjana tijdens mijn vierjarig verblijf gevangen heeft door gebruik te maken van die gewoonte.

Dit durf ik hier constateeren, dat zoodra men hunne prooi op de plaats zelve als lokaas (loemat of eupan) gebruikt, men zeker kan zijn van het resultaat.

(41) Oosting geeft voor ñingkĕr op: een mensch of dier, een aantal menschen of dieren omsingelen, insluiten.

In die beteekenis ken ik het niet, wel als jagersterm.

Ik heb het ook alleen uit den mond van paninggaran's gehoord. Voor omsingelen of insluiten gebruikte men $\mathrm{n}$ g ĕpoeng.

Onder ningkĕr verstaat de Zuid-Bantĕnsche jager het volgende.

De bosschen van dit deel der residentie zijn zeer uitgestrekt en bijzonder wildrijk. Herten (mandjangan) reebokken (m ĕntjĕk) rhinocerossen (badak), wilde varkens (gahil), tijgers (ma oeng, 5e Volgr. VI. 
lakbok, kĕroed, gohgor $\left(^{*}\right)$, dwergherten (peutjang) vindt men er in overvloed. Van de jacht, voornamelijk op herten en rhinocerossen, maakt men dan ook een bepaald bedrijf, dat geene geringe voordeelen oplevert.

Ik herinner mij, dat indertijd in de aan de Preanger Regentschappen grenzende desa's van $\mathrm{Tjilangkahan} \mathrm{de} \mathrm{badakjagers}$ aangeslagen werden voor $f 8$ in de bedrijfsbelasting - dus op eene jaarlijksche verdienste van $f 400$.

Een enkele badak brengt $f 150$ en meer op ( $\dagger$ )

Om zijne uitgestrektheid is het niet mogelijk door de drijvers het geheele bosch te laten afloopen. Men moet de drijfjachten telkens in dat gedeelte daarvan houden, waar men denkt dat het wild zich ophoudt.

De herten en rhinocerossen doen zich des avonds te goed aan den aanplant der bevolking of aan het jonge gras op de djami's en reuma's.

Even voor zonsopgang, tusschen vier en vijf uur, begeeft zich een der jagers naar den boschrand. Dat is de tijd, dat die dieren weder boschwaarts keeren om te slapen. Hij onthoudt de plek waar bijv. het hert het bosch is binnengegaan, wacht een uurtje en volgt dan voorzichtig het spoor.

(*) Maoeng noemt men den gewonen koningstijger (Felis tigris). Is hij van meer dan gewone grootte, zoo heet hij lakbok. De kĕroed is de gevlekte tijger (Felis pardus); evenzoo - maar van eene kleinere soort - de gohgor.

$(\dagger)$ In de allereerste plaats heeft eene groote waarde de hoorn - tjoela van den rhinoceros. Ik mag wel als bekend veronderstellen, dat hij eene belangrijke plaats inneemt in de inlandsche en chineesche pharmacopea. Borstkwalen, slangenbeten, kneuzingen - in- zoowel als uitwendige - vergiftigingen worden volgens beweren van den inlandschen en ehineeschen medicus daarmede genezen.

Dan volgen de hoektanden - měnoer -, die in ringen gevat worden. En eindelijk het vel, dat men gebruikt als een middel tegen de hama koengkang (Stenocoris varicornis, behoorende tot de groep der lygaeĩdae, meer bekend onder den Javaansehen naam errisaskion/ of den Bataviaasch-maleischen بإلث bålang, săngit.

Dit insect, dat zich in zwermen vertoont, wanneer de aren uit de padihalmen juist te voorschijn zijn gekomen en in éên enkelen nacht een gebeelen aanplant vernielen kan, wordt - alhoewel zelf een ondragelijken stank verspreidend - door onaangename geuren verdreven.

Men snijdt het vel van den rhinoceros aan repen, droogt het en verbrandt het op de sawah, zoodra men de komst dier insecten vreest.

Ook voert men de gedroogde vellen naar Batavia uit, waar chineezen ze opkoopen om er eene soort kĕroepoek (gebak van deeg uit fijn gemaakt vleesch, van gekookten visch en wat sagomeel; gedroogde repen van gekookte buffel of koehuid, die, wanneer men ze wil gebruiken, in olie gebakken worden) van te bereiden. 
Een ervaren jager zal dadelijk ten naastenbij kunnen nagaan, in welke doengoes of roejoek (*) het dier eene schuilplaats heeft gezocht.

Om zich daarvan te overtuigen loopt hij er om heen. Gaat het spoor door, zoo is dat een bewijs, dat hij zich vergist heeft. Op dezelfde wijze zet hij zijn onderzoek voort. Loopt het dood, dan houdt het wild zich daar werkelijk op.

Indien men eene drijfjacht houden wil, keert hij naar de lĕmboer terug, waarschuwt zijne gezellen (batoer), die zich met hunne jachthonden naar de plek begeven om het dier op te drijven.

Gaat hij echter er alleen op uit, dan klimt hij in de nabijheid in een hoogen boom, van waar hij het omliggend terrein kan overzien.

Tegen tien à elf uur verlaten de herten hunne legers om voedsel te zoeken.

Uit zijn hoog standpunt kan hij het exemplaar, dat zich in het boschje bevindt, gemakkelijk neerschieten.

Op de hierboven omschreven wijze onderzoeken, waar een wild dier een leger heeft, noemt men ningkĕr.

$\mathrm{Ningkĕran:} \mathrm{op} \mathrm{eene} \mathrm{omzichtige} \mathrm{wijze} \mathrm{de} \mathrm{schuilplaats} \mathrm{van} \mathrm{een}$ wild dier opsporen.

Men zou het woord het best teruggeven met: isoleeren, in afsluiting brengen.

(42) Onder de menak menak verstaat men in dat deel van Bantĕn, waar de bevolking Soendaneesch spreekt, gewoonlijk het gild der inlandsche ambtenaren, onafhankelijk van hunne afkomst.

Terwijl overal elders slechts bij uitzondering iemand uit de volksklasse het in de ambtelijke wereld tot eene aanzienlijke hoogte brengt, is het in deze residentie van het eiland $\mathrm{J}$ a $\mathrm{v}$ a herhaaldelijk voorgevallen. Een der regenten van het Wester Regentschap - bekend als Dalĕm Bontjel - is toekang djoekoet (grassnijder) geweest.

De vorige regent van het Zuider-Regentschap, Ra d e n T o e m ĕnggoeng Soeta angoen angoen, was de zoon van Dĕmang $\mathrm{Sahab}$, in den sultanstijd eevoudig ngabeui (desahoofd) van Tjikareo.

Patih Dĕroes, grootvader van den tegenwoordigen regent van het Noorder Regentschap, Raden Adipati Soetadiningrat, een eerbiedwaardig hoofd, versierd met de gouden medaille voor burgerlijke verdiensten, stamde volgens de overlevering van de Badoejs af en begon zijne loopbaan als ngabeui van Lĕbak Parahijang.

(§) Boschje, groot genoeg om bijv. er zich in te verbergen. 
Een der voorgangers van Raden Adipati Soetadiningrat, de bekende Raden Adipati Tjondrå Nĕgårå kwam onder den naam van $\mathrm{Si} B$ asoedin als kok van een resident uit $\mathrm{Midden}$ $J_{a v a}$ in Bantĕn, leerde in zijne vrije uren van de magangs op het gewestelijk bureau lezen en schrijven, trad als djoeroe toelis in 'slands dienst, klom hooger en hooger op en eindigde zijn leven als eervol ontslagen boepati, terwijl de Indische regeering bij wijze van belooning zijn verzoek toestond om zijn stiefzoon $R$ aden Toemĕnggoeng Pandji Gondå. Koesoemå - toenmaals regent van het Midden-Regentschap - tot zijn opvolger te benoemen.

De sadjarah's der mindere inlandsche ambtenaren - wadana's, assistent wadana's, om niet van schrijvers en mantri's te spreken bevatten dikwijls deze toelichting aangaande de afkomst der betrokkenen: "toeroenan orang kĕtjil sadja, tida bĕrsanak dĕngan radja radja ataw boepati boepati" - van geringe afkomst, niet verwant aan vorsten of regenten.

Menigeen zal kunnen getuigen, dat die ambtenaren niet onde ${ }^{r}$ de slechtsten gerekend moeten worden.

(43) In het Preanger-dialect tiloe.

(44) In het Preanger-dialect s ĕgor.

(45) Als jagersterm heeft $\mathrm{mogok}$ eene andere beteekenis.

Een dier, dat in het nauw gebracht wordt, tracht zich tot het uiterste te verdedigen en is in zoo'n geval kwaadaardiger dan anders. Hetzelfde heeft plaats met verwond of aangeschoten wild, - een banteng, maoeng, badak, - dat geen uitweg meer ziet om te ontkomen.

Het behoeft niet altijd uitgeput van vermoeienis te zijn.

Dikwijls zal men wel het tegendeel beweren.

Ten opzichte van zoo'n dier gebruikt men het woord mogok, dat is ongeveer hetzelfde als ons "standhouden."

(46) In het Preanger-dialect d a w o e han.

(47) Het woord ngala, dat oorspronkelijk halen, nemen, zoeken, inzamelen, inoogsten, af halen, roepen, ontbieden beteekent, - zie Coolsma - heeft als jagersterm de beteekenis van: er op uit gaan om iets te vangen.

Di Aweh aja tjina taloe ti Sadjra keur ngala gahil - te Aweh zijn er drie chineezen uit $\mathbf{S a d j}$ ra, die er op uit zijn gegaan om wilde varkens te vangen.

Ki Alka dititah koe dalëm pangsijoen ngala mandjangan di leuweung Mangpeng. - Ki Alka heeft van 
den gepensionneerden regent last gekregen om in het bosch van Mangpeng er op uit te gaan en herten te vangen.

(48) Loemat beteekent hetzelfde als eupan: lokaas.

Loemat kosong wil zeggen, dat men geen werkelijk lokaas gebruikt, maar bijv. een stuk hout in plaats van een achterbout van een karbouw in den wĕlĕng of in den val hangt.

Ik zal hier in het kort de verschillende systemen van tijgervallen, die men in $\mathrm{Zuid}$ Bantĕn toepast - met uitzondering van de wĕlĕng, beschrijven.

De tjara is een hok, dat aan den grond bevestigd wordt, vervaardigd is van zwaar hout, den vorm heeft van een driezijdig prisma en met eene valdeur gesloten wordt. Gebruikt men een levend dier als lokaas, dan wordt het zóó geplaatst, dat de tijger er niet bij komen kan.

De pigasol berust op hetzelfde beginsel, met uitzondering dat de vorm die is van een parallelepipedum en men voor materiaal neemt het harde gedeelte van den stam (r o ejoeng) eens kawoeng palms (Arenga sacharifera, natuurlijke familie der Palmeae.)

In Midden-Java noemt men deze soort val ถெarqaì.

Somtijds is de pigasol vervoerbaar en rust dan op vier houten wielen ( $\mathrm{g}$ ĕlĕb ĕg).

De pigĕboeg bestaat uit een drietal zware boomstammen gewoonlijk stammen van den ki-sĕmpoer (Dillenia a urea, natuurlijke familie der Dilleniaceae) die op den tijger neervallen, zoodra hij aan de loemat trekt, en hem door hun gewicht schier te pletter drukken.

Omtrent de biraloek zie men mijne "Bijdrage tot de kennis van het Bantěnsch dialect der Soendaneesche taal."

(49) In het Preanger-dialect bito e.

(50) In het Preanger-dialect wa likat.

(51) Vóór de indienststelling der assistent wadana's was het voor een districtshoofd zeer moeielijk om de bevelen van het europeesch bestuur bij elken dja ro afzonderlijk door zijn hulppersoneel over te laten brengen.

Buiten bemoeienis van het europeesch bestuur ontstonden de lo er a h-schappen.

Een zeker aantal desa's - drie, vier, vijf werden tot een geheel vereenigd onder een loerah, die voor de bekendmaking dier bevelen binnen zijn ressort zorgde.

Overigens verschilde zijn werkkring niet van dien zijner andere collega's. 
De groepeering van desa's is - voor zoover ik weet - nooit en nergens officieel erkend.

In het Kĕndalsche heette het desahoofd, dat in zoo'n vereeniging


Banjoem as asarinasl.

Tegenwoordig hebben de loerahschappen geen raison d'être. Toch blijven zij in de herinnering van het volk voortleven. De kleine man zal bijv. het hoofd der desa Saireun in Paroeng Koedjang, Rahong in Tjilangkahan steeds den titel van loerah of roerah geven. Andere djaro's worden met djoeragan aangesproken.

(52) Di boemi djoeragan wadana - in de woning van den wadana. In den Zuid-Bantĕnschen tekst lezen wij: "di boemina djoeragan wadana." In de Preangersche overzetting is het achtervoegsel na, hetwelk het bezittelijk voornaamwoord van den derden persoon aanduidt, weggelaten, omdat in dit dialect de regel geldt, dat als de bezitter genoemd wordt, men achter de bezitting het bezitttelijk achtervoegsel niet mag bezigen.

Of het verschil, dat het Zuid-Bantĕnsch te dien opzichte daarmede oplevert, een gevolg is van Javaanschen invloed uit het Noorder Regentschap en van Maleischen invloed uit de residentie Batavia dan wel van ouds zoo is, is moeielijk uit te maken.

In de pantoenverhalen der Badoejs (*) wier taal weinig vreemden invloed heeft ondervonden $(\dagger)$, vinden wij het achtervoegsel nu eens wel dan eens niet gebruikt, bijv. in het patoenverhaal Raden Tĕgal: "Ajeuna njaritakeun ramana Raden Tĕgal", "Tidinja pawarangna ki Mananggong njiram".

In dezelfde lalakon lezen wij daarentegen: Papanggih djeung pawarang Praboe Rangga Kantjana", in Panamang Sari: "Kĕlĕkap sare poetra dalĕm dina pangkonan Ratoe Manik", in Ranggah Sena: "Geus njampak papanggoengan kagoengan Praboe Moending Wangi.

NB. De letters $\mathrm{k}$ en $\mathrm{l}$ beteekenen respectievelijk $\mathrm{k}$ as ar en lĕ $\mathrm{m}$ ĕs.

$\left(^{*}\right)$ Verg. mijne collectie in de Januari-aflevering van dit jaar der Bijdragen tot de Taal-, Land- en Volkenkunde van Nederlandsch-Indië.

( $\dagger$ ) Verg. het door mij bewerkte tweede gedeelte van het werk «De Badoejs», uitgegeven door het Koninklijk Instituut voor de Taal-, Land- en Volkenkunde van Nederlandsch-Indië. 